\title{
Reproductive Biology of Clethra alnifolia
}

\author{
Sandra M. Reed ${ }^{1}$ \\ Floral and Nursery Plants Research Unit, U.S. National Arboretum, Agricultural \\ Research Service, U.S. Department of Agriculture, Tennessee State University Otis \\ L. Floyd Nursery Research Center, 472 Cadillac Lane, McMinnville, TN 37110
}

Additional index words. summersweet, breeding, self-incompatibility, stigma receptivity

\begin{abstract}
Breeding efforts in Clethra alnifolia L., an ornamental shrub native to the Eastern U.S., are hindered by a lack of information on the reproductive behavior of this species. The objective of this study was to evaluate self-compatibility, time of stigma receptivity, and the relationship between time of pollen shed and stigma receptivity in $C$. alnifolia. Stigma receptivity and changes in floral morphology were monitored over a 7-day period beginning at flower opening. Pollen germination and pollen tube growth in styles were examined following self- and cross-pollinations using fluorescence microscopy. Seed set and germination were compared following self- and cross-pollinations. Anthers began to dehisce in 'Hummingbird' and 'Ruby Spice' the day after flowers opened, but stigmas did not become fully receptive to pollen until 2 days later. An increase in the length of pistils was observed following flower opening. Maximum elongation of pistils occurred at approximately the same time stigmas became receptive and could be utilized as an indicator of receptivity. While self-pollen tubes appeared to grow slightly slower than cross-pollen tubes, there was no indication of a self-incompatibility system acting at the stigmatic or stylar level in C. alnifolia. Self-pollinations of 'Hummingbird' and 'Ruby Spice' produced fewer seeds than did cross-pollinations of these cultivars. Germination of all seed obtained from this study was too poor to allow a comparison of germination rates of the self- and cross-pollinated seed. However, because a few self-progeny were obtained, emasculation is recommended when making controlled pollinations. The presence of a late acting self-incompatibility system or early-acting inbreeding depression was proposed as being responsible for the lower seed set following self-pollination.
\end{abstract}

The genus Clethra L. consists of about 70 species of deciduous and evergreen shrubs and small trees (Hamilton, 1985; Sleumer, 1967a, 1967b). Several Clethra species are cultivated as ornamentals, but the most widely grown member of the genus in the U.S. is C. alnifolia. Commonly known as sweet pepper bush or summersweet, this deciduous shrub is found in acid swamps and low, moist woods along the Coastal Plain from Maine to Louisiana (Wilbur and Hespenheide, 1967). It is valued for its dark green pest-resistant foliage, attractive racemes or panicles of fragrant white or pink flowers, and ability to grow under a wide range of environmental conditions. The species is rated hardy to USDA Cold Hardiness Zones 4 (Dirr, 1998).

Several cultivars of $C$. alnifolia are available in the marketplace, all of which originated as branch sports or were selected from open-pollinated seedling populations. The two most highly sought traits for new cultivars are compact plant habit and flower color. While both compact ('Hummingbird', 'Sotite', '16 Candles') and pink-flowered ('Ruby Spice', 'Pink Spires', 'Fern Valley Pink', 'Hokie Pink', and 'Fern Valley Late Sweet') cultivars have been selected from open-pollinated seedling populations, no compact, pink-flowered plants

Received for publication 13 Dec. 2005. Accepted for publication 10 Jan. 2006. Mention of trade names of commercial products in the publication is solely for the purpose of providing specific information and does not imply recommendation or endorsement by the U.S. Department of Agriculture.

${ }^{1}$ Research geneticist. To whom reprint requests should be addressed; e-mail sreed@blomand.net. have been identified. Controlled pollinations provide the best opportunity for developing cultivars with the desired combination of complementary traits.

Information on reproductive behavior of a species is essential for conducting an efficient plant breeding program. Little is known about the reproductive biology of $C$. alnifolia, other than it is bee-pollinated (Hemingson, 1986). An attempt to self-pollinate $C$. alnifolia resulted in only a few seed, none of which germinated (Reed etal., 2002), but the reason for this failure is not known. The objective of this study was to evaluate self-compatibility, time of stigma receptivity, and the relationship between time of pollen shed and stigma receptivity in $C$. alnifolia.

\section{Materials and Methods}

Plant materials. Clethra alnifolia 'Fern Valley Late Sweet', 'Hummingbird', 'Ruby Spice' and 'September Beauty' were grown in 56.8-L containers in full sun and micro-irrigated using spray stakes. Two plants each of 'Hummingbird' and 'Ruby Spice' and a single plant of each of the other cultivars were used in the study. Growing medium consisted of pine bark amended with $6.6 \mathrm{~kg} \cdot \mathrm{m}^{-3} 19 \mathrm{~N}-2.1 \mathrm{P}-7.4 \mathrm{~K}$ Osmocote Pro fertilizer (Scotts-Sierra Horticultural Products Co., Maryville, Ohio), 0.6 $\mathrm{kg} \cdot \mathrm{m}^{-3}$ Micromax (Scotts-Sierra Horticultural Products Co.), $0.6 \mathrm{~kg} \cdot \mathrm{m}^{-3}$ iron sulfate, and 0.2 $\mathrm{kg} \cdot \mathrm{m}^{-3}$ Epsom salts. Plants were brought into a greenhouse 4 to $5 \mathrm{~d}$ before flowers were emasculated.

Floral measurements. Open flowers were removed from tagged inflorescences of 'Hummingbird' and 'Ruby Spice'. The following morning, all unopened flowers were removed from these inflorescences, leaving only those flowers that had opened within the previous 18 h. Each day for $7 \mathrm{~d}$, beginning the day the flowers opened, three of the tagged inflorescences were removed. Five flowers from each inflorescence were observed using a stereomicroscope. Color of anthers, evidence of dehiscence and appearance of stigma were recorded. Lengths of stamens and pistil were determined for each flower. Stamen and pistil length data were analyzed by analysis of variance (ANOVA), with mean separation determined by Tukey's $t$ test at $P \leq 0.05$.

Pollinations. Before pollination, openflowers were removed from inflorescences. Flowers that were to be used as sources of pollen were covered with breathable plastic pollination bags (DelStar Technologies, Middletown, Del.) until pollen was collected. For the maternal parent, inflorescences were covered with pollination bags overnight. The following morning, all newly opened flowers were emasculated, all unopened flowers removed and pollination bags placed back over inflorescences. To collect pollen, inflorescences were held over Petri dishes and tapped lightly. Pollen was applied to stigmas using a fine-tipped brush. For selfpollinations, pollen was obtained from flowers on the same plant as the emasculated flower. After pollination, inflorescences were covered with pollination bags which remained on the plants for 2 weeks or until the last flower was collected.

Stigma receptivity. Time of stigma receptivity was evaluated over a seven-day period. Ten 'Hummingbird' $\times$ 'September Beauty' and ten 'Ruby Spice' $\times$ 'September Beauty' pollinations were made every day beginning on the day of emasculation (day of flower opening). Flowers were collected $48 \mathrm{~h}$ after pollination and placed into FAA fixative (18:1:1, 70\% ethanol:formalin:glacial acetic acid) (Johansen, 1940). After $48 \mathrm{~h}$ at room temperature in fixative, flowers were transferred to $70 \%$ ethanol where they were stored for up to 2 months. Before staining, flowers were rinsed for $30 \mathrm{~min}$ in distilled water and then softened using $8 \mathrm{~N} \mathrm{NaOH}$ for $7 \mathrm{~h}$. Flowers were rinsed in distilled water overnight and then transferred to $0.1 \%(\mathrm{w} / \mathrm{v})$ aniline blue in $0.1 \mathrm{~N} \mathrm{~K}_{3} \mathrm{PO}_{4}$ for $1 \mathrm{~h}$ (Martin, 1959).

After staining, the pistil was placed on a microscope slide in a drop of aniline blue stain, squashed under a cover slip, and observed using an Olympus BX-60 microscope (Olympus America, Inc., Melville, N.Y.) equipped with a 100-W high-pressure Hg lamp and an UMNV near-ultraviolet (400 to $410 \mathrm{~nm}$ ) filter. Callose was observed as a bright yellow-green fluorescence and was used to detect pollen germination and growth of the pollen tubes through the styles. Percentage of flowers in which germinated pollen was present was determined for each treatment. The longest pollen tube in each style was measured using an ocular micrometer. Mean pollen tube length was calculated for each treatment using only those flowers in which pollen germination 

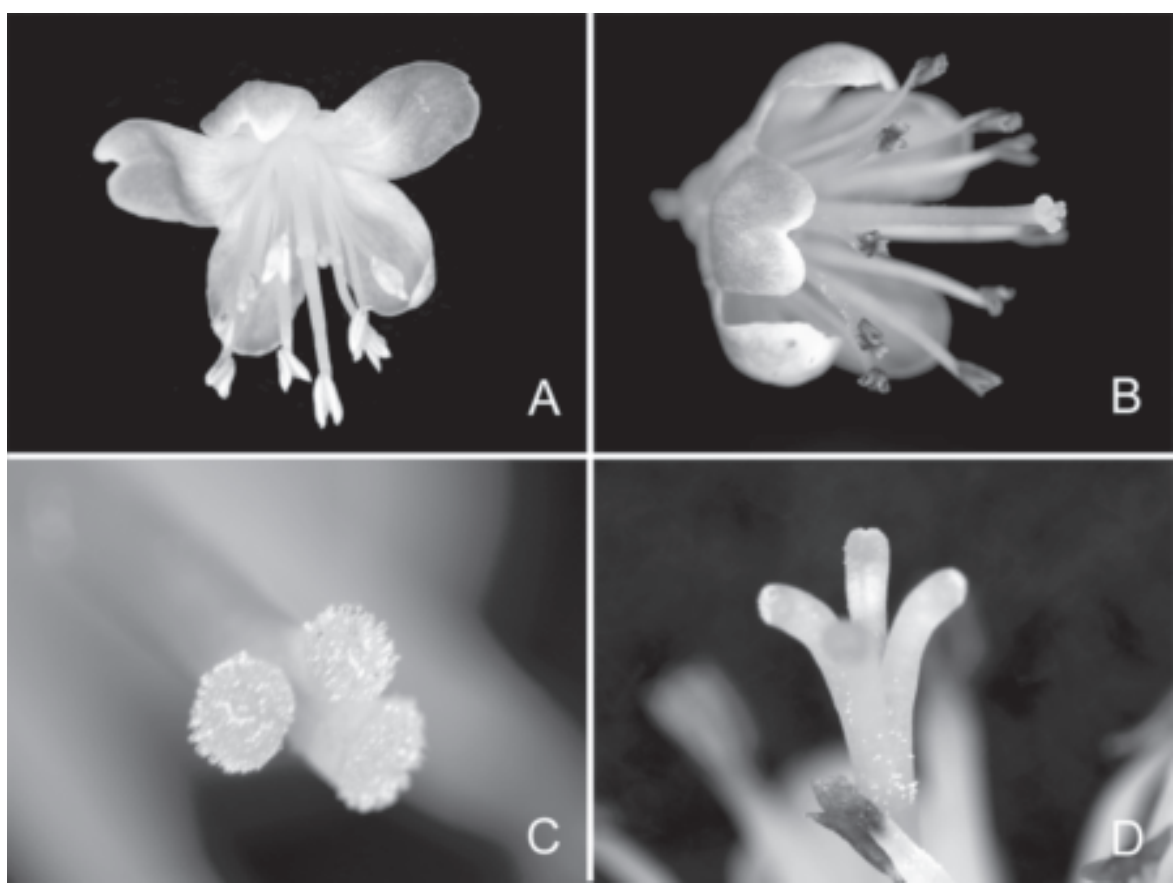

Fig. 1. Floral changes in Clethra alnifolia following flower opening. (A-B) Changes in anther color and pistil length in 'Ruby Spice' from the day of flower opening (A) to $4 \mathrm{~d}$ later (B). Separation of stigmas $3 \mathrm{~d}$ after flowering opening in 'Ruby Spice' (C) and 'Hummingbird' (D). was observed. Pollen tube length data were analyzed by analysis of variance (ANOVA), with mean separation determined by Tukey's $t$ test at $P \leq 0.05$, using SigmaStat software ver. 3.0 (SPSS, Chicago).

Self-incompatibility. At least 100 'Ruby Spice' $\times$ 'Hummingbird', 'Ruby Spice' self, 'Hummingbird' $\times$ 'Ruby Spice' and 'Hummingbird' self pollinations were made $4 \mathrm{~d}$ after flowers were emasculated. Ten flowers from each set of cross- and self-pollinations were collected at 2, 4, 8, 24, and $48 \mathrm{~h}$ after pollination. The remaining flowers of each pollination were allowed to remain on the plants until seeds were collected. Ten 'September Beauty' × 'Fern Valley Late Sweet', 'September Beauty' self, 'Fern Valley Late Sweet' × 'September Beauty' were also made $4 \mathrm{~d}$ after emasculation and collected $48 \mathrm{~h}$ after pollination.

Flowers were fixed and pistils stained as described above. Percent flowers with germinated pollen and mean pollen tube length were calculated for each treatment. Student's t-test was used to compare pollen tube length between each set of cross- and self-pollinations at each collection time.

Seed capsules from the controlled pollinations and from 30 'Ruby Spice' open-pollinations were collected in October, placed in paper bags and kept at $5{ }^{\circ} \mathrm{C}$ until completely dry. Capsules were crushed and seeds separated from debris using a stereomicroscope. Number of seeds per capsule was determined and seeds from each type pollination bulked. Seed were sown on the surface of a commercial seed propagation mix (Grow Mix \#1, Morton's Horticultural Products, Inc., McMinnville, Tenn.) in shallow $(3 \mathrm{~cm})$ seedling flats, which were placed in a heated greenhouse. Seed trays were bottom-watered daily and were provided and 'Fern Valley Late Sweet' self pollinations with bottom heat. With the exception of 'Ruby Spice' self-pollinated seed, germination was tested using three 50 -seed samples of each type pollination. Since self-pollinations of 'Ruby Spice' yielded less than 150 seed, the seed produced was divided into three equal batches before sowing. Number of seed germinated was determined 6 weeks after sowing.

\section{Results}

Changes in floral morphology. When 'Hummingbird' and 'Ruby Spice' flowers first opened, anthers were beige, there was no sign of anther dehiscence and the stigmatic lobes were tightly compressed (Fig. 1A). The following day the anthers had become darker in color and had dehisced in $100 \%$ of the 'Hummingbird' and $87 \%$ of the 'Ruby Spice' flowers. In both cultivars, $2 \mathrm{~d}$ after flowers opened, anthers were dark brown in color, all flowers showed evidence of anther dehiscence and stigmas had separated. Separation of the stigmas was much more pronounced in 'Hummingbird' than in 'Ruby Spice' (Fig. 1C-D). While a slight lengthening of the 'Ruby Spice' stamen was observed during the course of the study, no increase in stamen length was noted in 'Hummingbird' (Table 1). Pistils of both cultivars increased dramatically in length, especially during the first $3 \mathrm{~d}$ following flower opening (Table 1, Fig. 1B). ing on the stigmatic surface of $C$. alnifolia were easily detected (Fig. 2A). Although some background fluorescence was present in the styles, callose plugs fluoresced brightly and were highly visible at $200 \times$ magnification (Fig. 2B). No germinated pollen was observed on stigmas of 'Hummingbird' or 'Ruby Spice' flowers that were pollinated on the day the flowers opened or the following day. Pollen germinated on all 'Hummingbird' and $90 \%$ of the 'Ruby Spice' flowers that were pollinated $2 \mathrm{~d}$ after flowers opened; however, pollen tube length was considerably shorter in styles of 3 to $6 \mathrm{~d}$ after flower opening (Table 2).

Self-incompatibility. While pollen had germinated in only a few 'Hummingbird' flowers collected $2 \mathrm{~h}$ after pollination, all of the 'Hummingbird' flowers collected 4 or more $\mathrm{h}$ after pollination showed evidence of pollen germination. Differences in pollen tube length between 'Hummingbird'self-and cross-pollinations were observed in flowers collected 4,8 or $24 \mathrm{~h}$ after pollination. By $24 \mathrm{~h}$ after pollination, pollen tubes had reached the bottom of the style in $40 \%$ of the 'Hummingbird' cross-pollinations, but none had penetrated ovules. None of the pollentubes in the 'Hummingbird'self-pollinations had reached the bottom of the style at $24 \mathrm{~h}$ after pollination. By $48 \mathrm{~h}$ after pollination, pollen tubes had reached the bottom of the styles and had penetrated ovules in all 'Hummingbird'selfand cross-pollinated flowers. No differences in pollen tube length were observed between selfand cross-pollinated 'Hummingbird' flowers collected $48 \mathrm{~h}$ after pollination.

Pollen germination was observed in $80 \%$ of the cross-pollinated 'Ruby Spice' flowers collected $2 \mathrm{~h}$ after pollination, but no pollen had germinated in any of the 'Ruby Spice' self-pollinated flowers collected at this time (Table 3). Pollen had germinated in almost all of the self- and cross-pollinated 'Ruby Spice' flowers collected 4 or more $h$ after pollination. In 'Ruby Spice', a difference in pollen tube length between self-and cross-pollinations was observed only in flowers that had been collected $24 \mathrm{~h}$ after pollination. At this time, pollen tubes had reached the bottom of the styles in all of the 'Ruby Spice' cross-pollinated flowers and had penetrated at least one ovule in $50 \%$ of
Stigma receptivity. Pollen grains germinatthese flowers than in those that were pollinated

Table 1. Changes in stamen and pistil length of Clethra alnifolia 'Hummingbird' and 'Ruby Spice' during the week following flower opening.

\begin{tabular}{|c|c|c|c|c|}
\hline \multirow{2}{*}{$\begin{array}{l}\text { Days after } \\
\text { flowers opened }\end{array}$} & \multicolumn{2}{|c|}{ Mean stamen length $(\mathrm{mm})^{\mathrm{z}}$} & \multicolumn{2}{|c|}{ Mean pistil length (mm) } \\
\hline & Hummingbird & Ruby Spice & Hummingbird & Ruby Spice \\
\hline$\overline{0}$ & $7.0 \mathrm{ab}$ & $8.3 \mathrm{~b}$ & $4.7 \mathrm{c}$ & $4.5 \mathrm{~d}$ \\
\hline 1 & $7.0 \mathrm{ab}$ & $8.2 \mathrm{~b}$ & $5.0 \mathrm{c}$ & $5.1 \mathrm{~d}$ \\
\hline 2 & $7.1 \mathrm{a}$ & $8.6 \mathrm{ab}$ & $7.1 \mathrm{~b}$ & $7.2 \mathrm{c}$ \\
\hline 3 & $6.7 \mathrm{ab}$ & $8.7 \mathrm{ab}$ & $7.9 \mathrm{a}$ & $10.1 \mathrm{~b}$ \\
\hline 4 & $6.5 \mathrm{~b}$ & $8.8 \mathrm{ab}$ & $8.0 \mathrm{a}$ & $10.7 \mathrm{ab}$ \\
\hline 5 & $6.9 \mathrm{ab}$ & $8.7 \mathrm{ab}$ & $8.3 \mathrm{a}$ & $10.5 \mathrm{ab}$ \\
\hline 6 & $6.7 \mathrm{ab}$ & $9.1 \mathrm{a}$ & $8.2 \mathrm{a}$ & $10.9 \mathrm{a}$ \\
\hline
\end{tabular}

${ }^{2}$ Values within a column followed by the same letter are not significantly different based on Tukey's $t$ test $(P \leq 0.05) ; \mathrm{n}=15$ 


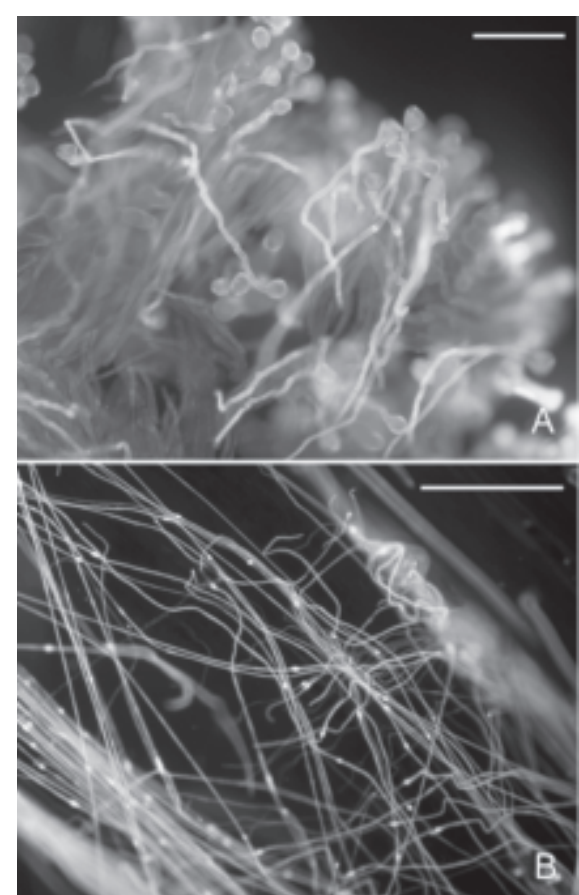

Fig. 2. Pollen germination and pollen tube growth in Clethra alnifolia 'Ruby Spice'. (A) Pollen germinating on stigmas $4 \mathrm{~h}$ after pollination. (B) Pollen tubes with callose plugs in styles 24 $\mathrm{h}$ after pollination. $\mathrm{Bar}=100 \mu \mathrm{m}$.

the flowers. In contrast, pollen tubes had not reached the bottom of the style in any of the 'Ruby Spice' self-pollinated flowers collected $24 \mathrm{~h}$ after pollination. By $48 \mathrm{~h}$ after pollination, no difference in pollen tube length between 'Ruby Spice' self- and cross-pollinated flowers was noted and pollen tubes had penetrated ovules in $90 \%$ of the self-pollinations and $100 \%$ of the cross-pollinations.

There was no difference in pollen tube length between self- and cross-pollinations of 'September Beauty' collected $48 \mathrm{~h}$ after pollination. Pollen tubes had reached the bottom of the styles and penetrated ovules in all of the 'September Beauty' flowers. While pollen tubes had reached the bottom of the style in 'Fern Valley Late Sweet' flowers by $48 \mathrm{~h}$ after pollination, a difference in pollen tube length was found between the self- and

Table 2. Effect of time of pollination on pollen tube growth in Clethra alnifolia 'Hummingbird' and 'Ruby Spice'.

\begin{tabular}{lcc}
\hline Days after & \multicolumn{2}{c}{ Mean pollen tube length $(\mathrm{mm})$} \\
\cline { 2 - 3 } flower opening & Hummingbird $\times$ September Beauty & Ruby Spice $\times$ September Beauty \\
\hline 0 & --- & --- \\
1 & -- & -- \\
2 & $1.8 \mathrm{~b}$ & $2.9 \mathrm{~b}$ \\
3 & $8.5 \mathrm{a}$ & $8.1 \mathrm{a}$ \\
4 & $9.6 \mathrm{a}$ & $10.4 \mathrm{a}$ \\
5 & $9.0 \mathrm{a}$ & $10.4 \mathrm{a}$ \\
6 & $9.7 \mathrm{a}$ & $7.1 \mathrm{a}$ \\
\hline
\end{tabular}

${ }^{z}$ Mean separation within a column based on Tukey's $t$ test $(P \leq 0.05)$. Missing data indicates that pollen did not germinate.

Table 3. Pollen germination and pollen tube length in cross- and self-pollinations of four cultivars of Clethra alnifolia.

\begin{tabular}{|c|c|c|c|c|c|}
\hline \multirow[b]{2}{*}{ Pollination } & \multicolumn{5}{|c|}{ Hours after pollination } \\
\hline & 2 & 4 & 8 & 24 & 48 \\
\hline \multicolumn{6}{|l|}{ Flowers with germinated pollen (\%) } \\
\hline Ruby Spice $\times$ Hummingbird & 80 & 80 & 100 & 100 & 100 \\
\hline Ruby Spice selfed & 0 & 100 & 90 & 100 & 100 \\
\hline Hummingbird $\times$ Ruby Spice & 40 & 100 & 100 & 100 & 100 \\
\hline Hummingbird selfed & 10 & 100 & 100 & 100 & 100 \\
\hline September Beauty $\times$ Fern Valley Late Sweet & --- & --- & --- & --- & 100 \\
\hline September Beauty selfed & --- & --- & --- & --- & 100 \\
\hline Fern Valley Late Sweet $\times$ September Beauty & --- & --- & --- & --- & 100 \\
\hline Fern Valley Late Sweet selfed & --- & --- & --- & --- & 100 \\
\hline \multicolumn{6}{|l|}{ Mean pollen tube length $(\mathrm{mm})^{\mathrm{z}}$} \\
\hline Ruby Spice $\times$ Hummingbird & 0.1 & $0.4 \mathrm{a}$ & $1.1 \mathrm{a}$ & $10.4 \mathrm{a}$ & $10.2 \mathrm{a}$ \\
\hline Ruby Spice selfed & --- & $0.3 \mathrm{a}$ & $0.9 \mathrm{a}$ & $7.1 \mathrm{~b}$ & $10.6 \mathrm{a}$ \\
\hline Hummingbird $\times$ Ruby Spice & 0.1 & $0.4 \mathrm{a}$ & $1.2 \mathrm{a}$ & $6.5 \mathrm{a}$ & $8.7 \mathrm{a}$ \\
\hline Hummingbird selfed & 0.1 & $0.3 \mathrm{~b}$ & $0.7 \mathrm{~b}$ & $5.3 \mathrm{~b}$ & $8.5 \mathrm{a}$ \\
\hline September Beauty $\times$ Fern Valley Late Sweet & --- & --- & --- & --- & $8.0 \mathrm{a}$ \\
\hline September Beauty selfed & --- & --- & --- & --- & $8.1 \mathrm{a}$ \\
\hline Fern Valley Late Sweet $\times$ September Beauty & --- & --- & --- & --- & $10.4 \mathrm{a}$ \\
\hline Fern Valley Late Sweet selfed & --- & --- & --- & --- & $9.6 \mathrm{~b}$ \\
\hline
\end{tabular}

${ }^{\mathrm{z}}$ Mean separation within maternal cultivar and time of collection based on paired $t$ test $(P \leq 0.05)$.

Table 4. Seed set and seed germination following self- and cross-pollination of Clethra alnifolia 'Hummingbird' and 'Ruby Spice'.

\begin{tabular}{lccccc}
\hline $\begin{array}{l}\text { Maternal } \\
\text { parent }\end{array}$ & $\begin{array}{c}\text { Type } \\
\text { pollination }\end{array}$ & $\begin{array}{c}\text { Pollinations } \\
\text { forming seed } \\
\text { capsules }(\%)\end{array}$ & $\begin{array}{c}\text { Capsules } \\
\text { with seed } \\
(\%)\end{array}$ & $\begin{array}{c}\text { No. seed/ } \\
\text { capsule } \\
(\text { mean } \pm \text { SE) }\end{array}$ & $\begin{array}{c}\text { Seed germination (\%) } \\
(\text { mean } \pm \text { SE) }\end{array}$ \\
\hline Hummingbird & Self & 100 & 93 & $6.2 \pm 0.5$ & $24.7 \pm 7.5$ \\
Hummingbird & Cross & 95 & 100 & $52.2 \pm 1.9$ & $37.3 \pm 2.9$ \\
Ruby Spice & Self & 93 & 44 & $1.5 \pm 0.3$ & $2.0 \pm 1.2$ \\
Ruby Spice & Cross & 100 & 98 & $4.4 \pm 0.1$ & $11.3 \pm 1.8$ \\
Ruby Spice & Open & -- & 96 & $5.4 \pm 0.5$ & $3.3 \pm 2.4$ \\
\hline
\end{tabular}

${ }^{\mathrm{z}}$ Only capsules with one or more seed included in this calculation. cross- pollinated flowers. Pollen tubes had penetrated ovules in $100 \%$ of the 'Fern Valley Late Sweet' cross-pollinated flowers, but in none of the self-pollinations.

Almost all of the self- and cross-pollinations produced seed capsules; however, many of those obtained from the 'Ruby Spice' self-pollinations contained no seed (Table 4). Seed capsules resulting from cross-pollinations contained three to eight times more seed than self-pollinated capsules of the same cultivar. 'Ruby Spice' cross-pollinated capsules contained $<10 \%$ of the number of seed found in 'Hummingbird' cross-pollinated capsules; however, seed number was similar in crossand open-pollinated 'Ruby Spice' capsules. All seed samples germinated poorly and very little difference in germination rates between seed from self- and cross-pollinations was observed.

\section{Discussion}

While anthers of C. alnifolia 'Hummingbird' and 'Ruby Spice' dehisced the day after the flowers opened, stigmas did not become fully receptive until $2 \mathrm{~d}$ later and remained receptive for at least $4 \mathrm{~d}$. Maximum elongation of pistils occurred at approximately the same time stigmas became receptive and could be utilized as an indicator of receptivity. Previously, C. alnifolia flowers were pollinated on or near the day flowers opened (Reed et al., 2002). Since good set seed was obtained from those pollinations, it appears C. alnifolia pollen can remain viable for several days after being applied to the stigma.

The temporal separation of anther dehiscence and stigma receptivity is referred to as dichogamy (Bertin, 1993). Clethra alnifolia exhibits protandry, a form of dichogamy wherein pollen is shed before stigmas becoming receptive. Dichogamy is often regarded as a mechanism for preventing self-fertilization. However, only protogyny, a form of dichogamy in which stigma receptivity precedes anther dehiscence, appears effective for enforcing outcrossing (Bertin, 1993). The separation of male and female function that we observed in this study would likely not be sufficient to prevent self-fertilization of C. alnifolia in nature, especially considering the apparent longevity of $C$. alnifolia pollen.

Self-incompatibility (SI) is the inability of a plant with functional male and female gametes to set seed when self-pollinated (Brewbaker, 1957). In sporophytic SI, germination of incompatible pollen is inhibited at the stigmatic surface, while gametophytic SI is manifested by an inhibition of pollen tube growth in the style (de Nettancourt, 1977). Pollen germinated freely following both self- and cross-pollinations of C. alnifolia 'Hummingbird' and 'Ruby Spice'. Only slight differences in growth rate between self- and cross-pollen tubes were observed. While it is possible that, if applied at the same time, cross-pollen tubes might have a competitive advantage over self-pollen tubes, there does not appear to be a barrier to self-fertilization acting at the stigmatic or stylar level in C. alnifolia. 
While initially thought to berare, self-incompatibility systems that operate at the ovarian or ovular level have been found to be much more common that originally thought, especially among woody species (Sage etal., 1994; Seavey and Bawa, 1986). These systems, which are collectively referred to as late-acting SI, involve inhibition of incompatible pollen tubes before the ovule is reached, pre-fertilization inhibition in the ovule, postzygotic rejection, and ovular inhibition of unknown cause. Since seed set was much lower in self-pollinations of 'Hummingbird' and 'Ruby Spice' than in cross-pollinations and there was no evidence of a sporophytic or gametophytic SI system, it is possible that C. alnifolia possesses a late-acting SI system. However, it is often difficult to differentiate between late-acting SI and earlyacting inbreeding depression (Charlesworth, 1985). Additional studies are needed to more clearly determine the cause of reduced seed set following self-pollination in C. alnifolia.

Because a substantial difference in number of seed per capsule was observed between 'Hummingbird' and 'Ruby Spice' cross-pollinations, open-pollinated seed capsules of 'Ruby Spice' were examined. Similar numbers of seed were present in the cross- and open-pollinated capsules. Cytological examination of $C$. alnifolia 'Hokie Pink', C. pringlei S. Wats. and their hybrid indicated that $C$. alnifolia is either an autotetraploid or a segmental allopolyploid (Reed, 2005). While 'Hokie Pink' exhibited bivalent pairing, it is possible that other $C$. alnifolia cultivars may show meiotic irregularities that could lead to poor seed set.

In contrast to a previous study (Reed et al., 2002), a few viable seeds were obtained from self-pollinations of C. alnifolia 'Hummingbird' and 'Ruby Spice'. Seed germination from all pollinations was too poor to allow conclusions to be made on the comparative viability of seed obtained from self-and cross-pollinations. Germination guidelines indicate that C. alnifolia seed do not have a stratification requirement and can be sown directly after collecting (Dirr and Heuser, 1987). In previous years, we have stored $C$. alnifolia seed at $4{ }^{\circ} \mathrm{C}$ for 2 months before sowing and have obtained good germination. Due to poor seed set from most of the pollinations, insufficient seed was available to determine if a chilling treatment would improve germination of the seed obtained from this study.

In summary, flowers of C. alnifolia should be emasculated when making controlled pollinations if the complete exclusion of self-progeny is desired. Even though it appears possible to obtain viable seed following self-pollination of $C$. alnifolia, large numbers of pollinations may be needed to produce sufficient numbers of self-progeny for inheritance studies. Seed set, from both self- and cross-pollinations, may vary depending on cultivar. Finally, further investigations into the long-term viability of and expression of inbreeding depression in $C$. alnifolia self-progeny are needed for estimating the value of self-pollination in genetic analyses and breeding programs with this species.

\section{Literature Cited}

Brewbaker, J.L. 1957. Pollen cytology and selfincompatibility systems in plants. J. Hered. 48:271-177.

Bertin, R.I. 1993. Dichogamy in angiosperms. Bot. Rev. 59:112-152.

Charlesworth, D. 1985. Distribution of dioecy and self-incompatibility in angiosperms, p. 237-268.
In: P.J. Greenwood and M. Slatkin (eds.). Evolution: Essays in honour of John Maynard Smith. Cambridge Press, Cambridge, U.K.

de Nettancourt, D. 1977. Incompatibility in angiosperms. Springer-Verlag, Berlin.

Dirr, M.A. 1998. Manual of woody landscape plants. Stipes Publ., Champaign, Ill.

Dirr, M.A. and C.W. Heuser, Jr. 1987. The reference manual of woody plant propagation: From seed to tissue culture. Varsity Press, Athens, Ga.

Hamilton, C.W. 1985. Notes on and descriptions of seven new species of Mesoamerican Clethraceae. Ann. Mo. Bot. Gard. 72:539-543.

Hemingson, J.C. 1986. The pollination biology of Clethra alnifolia L. (Clethraceae) PhD diss. Univ. Conn., Storrs.

Johansen, D.A. 1940. Plant microtechnique. McGraw-Hill, New York.

Martin, F.W. 1959. Staining and observing pollen tubes in the style by means of fluorescence microscopy. Stain Technol. 34:125-128.

Reed, S.M. 2005. Cytological analysis of a Clethra alnifolia 'Hokie Pink' $\times$ C. pringlei hybrid. HortScience 40:339-342.

Reed, S.M., Y. Joung, and M. Roh. 2002. Interspecific hybridization in Clethra. HortScience 37:393-397.

Sage, T.L., R.I. Bertin, and E.G. Williams. 1994. Ovarian and other late-acting self-incompatibility systems, p. 116-140. In: E.G. Williams, A.E. Clarke, and R.B. Knox (eds.). Genetic Control of self-incompatibility and reproductive development in flowering plants. Kluwer, Dordrecht, Neth.

Seavey, S.R. and K.S. Bawa. 1986. Late-acting self-incompatibility in angiosperms. Bot. Rev. 52:195-219.

Sleumer, H. 1967a. Monographia Clethracearum. Part I. Bot. Jahrb. Syst. 87:36-116.

Sleumer, H. 1967b. Monographia Clethracearum. Part. II. Bot. Jahrb. Syst. 87:117-175.

Wilbur, R.L. and H.A. Hespenheide. 1967. The genus Clethra (Clethraceae) in the United States. J. Elisa Mitchell Soc. 83:82-88. 